\title{
The effect of germination in barely on its chemical composition, nutritional value and rheological properties
}

\author{
Tesby M. R. Lotfy, Neveen.F.Agamy, Nashwa. M. Younes
}

1 Home Economics Department, Faculty of Specific Education, Alexandria University, Alexandria, Egypt

2 Department of Nutrition, High Institute of Public Health, Alexandria University, Alexandria, Egypt

\begin{abstract}
Barley is considered a functional food as it is a good source of antioxidants and dietary fiber such as $\beta$-glucan. The current study aims to evaluate the characteristics of common and germinated barley. This was done by estimating the effect of germination on the antioxidant content, the content of antinutritional factors, the content of amino acids, some vitamins and minerals, as well as the rheological properties (dough raising ability) of common and sprouted barley. Results indicated an improvement in the chemical composition of barley after germination. Germination of barley increased its content of folic acid, vitamin E, and vitamin B complex. The content of minerals such as chromium, magnesium and calcium also increased significantly upon germination. Anti-nutritional factors such as tannin and phytic acid decreased while amino acids such as lysine and leucine significantly increased after germination. Results also showed a significant increase in flavonoids and phenolic contents along with antioxidant activity in sprouted barley compared to normal barley. The study recommends promoting and encouraging consumption of sprouted barley products in Egypt.
\end{abstract}

Key words: germinated barely, amino acid, antioxidant activity, vitamins, minerals

\section{Introduction:}

Functional food science has gained momentum recently in response to the changing health status of developed countries. As healthcare costs and average life expectancy rise, the public has sought ways to become healthier and develop higher qualities of life. The concept of "functional food" developed as 
a convenient and in expensive solution to chronic health problems (Martirosyan \& Jaishree, 2018).Functional foods are defined as traditional food (conventional food) or food derived product which can be fortified or modified (enriched) to enhance its nutritive value and thereby improving physiological health status (Santini et al.,(2017); Shahidi ,2012). Whereas, nutraceuticals are as a whole food product or part of food (bioactive components from plant or animal source) which could be used as supplements or medicine (pills/capsule) to render various health promoting function in addition to its nutritional value ( Daliu et al.,( 2019); Santini \& Novellino , 2018).

Barley (Hordeum vulgare L) is a wonderful cereal grain that was used by ancient civilizations as a food for humans and animals. In addition barley water has been used for various medicinal purposes (Francois, 1996).Barley is a widely consumed cereal among the most ancient cereal crops. Almost 80-90\% of barley production is for animal feeds and malt, but now barley is gaining renewed interest as an ingredient for production of functional foods due to their concentration of bioactive compounds Jadhav et al., (1998). Barely is gaining more interest due to its nutritional value, especially because of the dietary fiber content and the presence of non-starch polysaccharides, barely is a rich source fiber providing beneficial Pejcz et al., (2017).

Germination is a process in which physical modification of endosperm is carried out to increase the bioactive compounds. During germination, starch degradation is very limited, despite the fact that starch degrading enzymes are synthesized. The total protein content of cereals increases slightly during germination due to more intensive degradation of other kernel components for respiration (Kaukovirta,2004). Germination process leads to structural modification and synthesis of new compounds with high bioactivity and can increase the nutritional value and stability of grains (Nonogaki,2010). During germination, storage molecules (proteins, starch) are degraded under enzymatic action. Added to, some bioactive compounds such as polyphenols, vitamins are newly synthesized. Sprouting affects also functional and sensory properties of barely. All modifications occurring during sprouting make sprouted barely seeds a functional ingredient, naturally enhanced by bioactive molecules. Its use in food industry would provide an added value Jribi et al., (2018).

Therefore, the present study aims to investigate the effect of germination process on chemical properties such as amino acid, antioxidant activities, antinutritional and rheological properties of barely after germination 


\section{MATERIALS AND METHODS}

\section{Materials:}

- A total of 10 kilograms of each varieties of Egyptian barely grain (Hordeum Vulgare) (Giza 126 and Giza 132) were purchased from Farm College of Agriculture, Alexandria University. Other components which were used in the preparing products were purchased from local markets in Alexandria, Egypt.

- The used chemicals and reagents were analytical grade and obtained from EL- Goumhorya Company, Egypt.

\section{Methods}

\section{Preparation of Germinated Barely}

\section{- Soaking}

Good seeds were separated from broken seeds, dust and foreign materials, and then soaked in water for 12 hours.

- Germination

The pre- soaked seeds were spread on wet cotton in aluminium baskets for 3-4 days until germination then, the germinated seeds were dried on air for 48 hours Youssef et al., (2013).

Chemical analysis

Chemical composition of barely and germinated barely raw were carried out in the central lab, Faculty of agriculture, University of Alexandria, whereas, moisture content, ash, crude protein contents, crud fiber and carbohydrate concentrations were determined according to the procedure described in Association of Analytical Chemist AOAC, (2000). Total fat determined by method described by Folch et al., (1957). $\beta$-glucan estimation was carried out according to the method of McCleary \& Codd,1991.

\section{Antioxidants activity (Free radical scavenging assay):}

The DPPH free radical scavenging activity assay was performed using a method adopted from Brand-Williams et al., (1995), Total flavonoids 
extraction was carried out using the method of Siddhuraju \& Becker ,2003. Total phenolic content was measured, the method reported by Makkar et al.,(1997).Extraction of phenolics from bakery products was carried out, with modifications, following the method reported by Siddhuraju \& Becker, 2003.

\section{Mineral content:}

$\mathrm{Fe}, \mathrm{Ca}, \mathrm{Mg}, \mathrm{Zn}$, were determined using Atomic Absorption Spectrophotometer (Shimadzu model AA- 6650) as described in Wall ,2006.

\section{Vitamins content:}

Vitamin E was colorimetrically estimated by HPLC technique as described by Batifoulier et al., (2005) was used for separation and quantification of folicacid, pyridoxine by a new reversed- phase chromatographic method.

\section{Determination of ant nutritional factors}

Qualitative and quantitative analysis of tannin, phytate and trypsin inhibitor were done in the Unit of analysis and scientific service, Faculty of Agriculture, Alexandria University. Trypsin inhibitor (TrI) was extracted and determined according to Hamerstrand et al., (1981).Tannin content of each blend was measured by the modified vanillin-hydrochloric acid method Price \& Butler, 1977. Phytic acid was determined following the procedure of Davies \& Reid ,1979.

\section{Amino acids composition using HPLC:}

The amino acids composition of experimental samples were determined using HPLC-Pico-Tag method according to Millipore Cooperative (1987). The Pico-Tag method, was described by Heinrikson \& Meredith ,1984and Cohen et al., (1989).

\section{Rheological properties:}

Rheological properties of dough were evaluated using Mixolab , extensograph and falling number according to American Association of Cereal Chemists [AACC] ,2000 Sample of $50 \mathrm{~g}$ was placed into the mixolab bowl and mixed. After tempering the solids, the water required for optimum consistency was added. Special attention was carried to the determination of the water absorbtion; in order to ensure the complete hydration of all the components Bonet et al., (2006). The running parameters of the mixolab device 
during the tests are: mixing rate $80 \mathrm{rpm}$, temperature of the first plateau $30 \mathrm{c}$, duration of the first plateau $8 \mathrm{~min}$, temperature of the second plateau $90 \mathrm{c}$, first temperature gradient $4 \mathrm{c} / \mathrm{min}$,duration of the second plateau $7 \mathrm{~min}$ ,second temperature gradient $4 \mathrm{c} / \mathrm{min}$, temperature of the third plateau $5 \mathrm{c}$ and duration of third plateau $5 \mathrm{~min}$ as described by Antanas et al. (2013).Falling number and gluten characters were measured according to (AACC, 2000).

\section{Statistical analysis of the data}

Data were fed to the computer and analyzed using IBM SPSS software package version 20.0. (Armonk, NY: IBM Corp)(Kirkpatrick \& Feeney, 2013) Quantitative data were described using mean, standard error of mean. Significance of the obtained results was judged at the 5\% level. The used tests were F-test (ANOVA) For normally distributed quantitative variables, to compare between more than two groups, and Post Hoc test (LSD) for pairwise comparisons. Student t-test For normally distributed quantitative variables, to compare between two studied groups. Kotz et al.( 2006)

\section{Results:}

The results and discussion of the research as follows: Proximate analysis of normal and germinated barely, Antioxidant activities, phenols, flavonoids, amino acid content, anti-nutritional factors, and the Rheological properties of normal and germinated barely.

\section{Gross chemical composition of normal and germinated raw barely}

Gross chemical composition and $\beta$-glucan of germinated barely compared to normal barely are shown in table (1).

The mean value of protein was $9.91 \%$ for normal barely while it was $12.81 \%$ for germinated barely. Protein is very important and main component to all living cells, the protein percentage is more in barely grains compared to other crops elevating the nutritional value of barely .During germination many components are breaking down to simpler forms of nutritional components Sangronis et al.,(2006). Protein was increased in the flour of germinated barely that could be attributed to the role of enzymes during germination which produce of some amino acids during protein synthesis Afify et al.,(2016). These results agreed with the results of Montanuci et al.,(2013) . Abdallah \& Abo El-Naga ,2013 they reported that barley protein content is ranging from $9.55 \%$ 
to $10.56 \%$. The crude protein increased after germination compared to whole barely flour.

The mean value of fat content of normal barely was $(2.53 \%)$ while in germinated barely flour was $(2.10 \%)$. These results are in agreement with many reports indicated that fats are 1-3\% in barely grains and very important in organization physical and chemical properties for barely grains as fatty acids support the embryo with nessecery nutrients during germination and also very important to transfer protein (Sharma et al.,( 2007); Youssef et al.,(2012); Cozzolino \& Degner, 2016).

Ash level decreased from 3.24 to $2.81 \%$ after germinated. These results agreed with the result of Donkor et al.,(2012) who stated that ash content of barley before and after germination was $(2.33 \%)$ and $(2.16 \%)$, respectively. While Hung et al., (2012) found that the ash content did not change significantly during the first $36 \mathrm{~h}$ of germination. The current results showed that the amount of ash are too small to be considered an important nutritional source.

Results indicated that the content of crude fibers was $4.75 \%$ for normal barely while $5.15 \%$ for germinated barely. Fibers are important bioactive components, namely prebiotics. Prebiotics represent an important category of functional foods. Prebiotics are polysaccharides and oligosaccharides that can be selectively fermented by probiotic bacteria native to the large intestine. There are numerous health benefits of prebiotics in terms of their roles as anticarcinogenic, anti-microbial, anti-hyperglycemic and anti-osteoporrotic agents along with their stimulatent activity Abou-Bakr et al.,( 2014).

Fiber rich foods are normally prescribed to diabetes for reduction of glycemic response to the food and consequently the need for insulin (Guillon $\&$ Champ, 2000). Supporting results finding by Koehler et al., (2007) who reported changes in fiber content may attribute to the fact that part of the seed fiber may be solubilized enzymatically during seed germination. Barley is now gaining renewed interest as a functional food ingredient because it is considered as a rich source of $\beta$-glucans (Brennan \& Cleary, 2005; Soares et al., (2007). The mean value of $\mathrm{N}$-free extract was $80.43 \%$ for normal barely while in germinated barely was $76.27 \%$. The tabulated results from Table (1) revealed that there were a significant differences in the mean value of moisture, protein and $\mathrm{N}$-free extract content of normal and germinated barely while there were no significant diferences in the mean value of fat, ash and crude fiber.

$\beta$-Glucan content of normal barely flour was $(6.50 \%)$ as compared with (7\%) in germinated barely as shown in table (1). These result incontrast with the results 
of Bamforth ,1982 ; Chandra et al., (1999), they reported that barely is rich in $\beta$ glucan compared to other grains, and germination decreases the content of $\beta$ glucan in barely, The reason of decreasing $\beta$-glucan level during germination is that $\beta$-glucan normally found in the endosperm , during germination endosperm walls are destroyed and make $\beta$-glucan free and mostly solubled because of hydrolysis of $\beta$-glukinase which known as (Lichenase and 4glucano Hydrolase) they are responsible for decreasing $\beta$-glucan content.

Table (1): Gross chemical analysis of normal and germinated barely

\begin{tabular}{||l|c|c|c|c|c||}
\hline $\begin{array}{c}\text { Parameters } \\
\text { (g/ 100g dry weight) }\end{array}$ & $\begin{array}{c}\text { Normal } \\
\text { barely } \\
\text { mean } \pm \text { SE }\end{array}$ & $\begin{array}{c}\text { Germinated } \\
\text { barely } \\
\text { mean } \pm \text { SE }\end{array}$ & $\begin{array}{c}\text { \% } \\
\text { change }\end{array}$ & $\mathbf{T}$ & P \\
\hline Crude Protein (\%) & $9.91 \pm 0.26$ & $12.81 \pm 0.26$ & 29.3 & $7.881^{*}$ & $0.001^{*}$ \\
\hline Fat content (\%) & $2.53 \pm 0.09$ & $2.10 \pm 0.46$ & -17.0 & 0.927 & 0.406 \\
\hline Ash content (\%) & $3.24 \pm 0.27$ & $2.81 \pm 0.18$ & -13.3 & 1.338 & 0.252 \\
\hline Crude fibers (\%) & $4.75 \pm 0.03$ & $5.15 \pm 0.16$ & 8.4 & 2.423 & 0.073 \\
\hline N-free extract (\%) & $80.43 \pm 0.23$ & $76.27 \pm 0.18$ & -5.1 & $14.233^{*}$ & $0.001^{*}$ \\
\hline B- Glucan (\%) & $6.50 \pm 0.36$ & $7.0 \pm 0.22$ & 7.7 & 1.194 & 0.299 \\
\hline
\end{tabular}

Data was expressed using Mean $\pm \mathrm{SE}$.

t: Student t-test

*: Statistically significant at $\mathrm{p} \leq 0.05$

\section{Antioxidant activity, phenols and flavonoids content in normal and germinated barely.}

A comparison between Antioxidant activity, phenols and flavonoids of normal and germinated barely are shown in table (2).

The total antioxidant activity which was measured by DPPH showed that, the DPPH score was increased from $56.60 \%$ for normal barely to $82.12 \%$ after germinated. It is also noticed that vlue of DPPH increased by $45.1 \%$ after germination. DPPH is a free radical compound that has been widely used to determine the free radical ability of various samples. Antioxidants are substances that can inhibit or diminish oxidizable substrate action (Amarowicz et al.,(2004); Kryston et al.,( 2011). 
It can be observed that the mean value of total flavonoids was 54.38 $\mathrm{mg} / 100 \mathrm{~g}$ in normal barely while, the level of flavonoids was increase to 102.0 $\mathrm{mg} / 100 \mathrm{~g}$ in germinated barely. Flavonoids and total phenolic compounds as $\mathrm{mg} / 100 \mathrm{~g}$ of normal and germinated barely are shown in table (2) .Flavonoids are a group of polyphenolic compounds, diverse in chemical structure and characteristics, found ubiquitously in plant. They provide colouring to various tissues including flowers (Winkel-Shirley, 2001; Davies et al.,(2012).These compounds serve essential functions in plant reproduction by recruiting pollinators and seed dispersers (Winkel-Shirley, 2002). They are strong antioxidants, free radical scavengers Agati et al.,(2012) and metal chelators that inhibit lipid peroxidation (Cook \& Samman, 1996). Flavonoids are also produced inducibly by plants during stress, ostensibly as a natural defence mechanism (Pollastri \& Tattini, 2011; Delaux et al.,(2012). Flavonoids are reported to have antioxidant, anticancer, anti-allergic, anti-inflammatory, anticarcinogenic and gastro protective properties (Harborne \& Williams, 2000; Yao et al.,(2004); Fardet, 2010).

Cereals have only small quantities of flavonoids Đorđević et al.,(2010), except barley that contains measurable amounts of catechin and some di and tri pro-cyanidins (McMurrough \& Baert, 1994; Naczk \& Shahidi, 2004). Barely flour in addition to its source of fibers and $\beta$ - Glucan is containing phenolic and flavonoids as anti-oxidants. Anti-oxidants are very important to save the body from heart diseases, save fats of oxidation and decrease heart and artries diseases and anti - inflammation (Han et al.,( 2007).

Germination can change the total phenolic content in seeds depending on the germination time and species. A high total Phenol content was found in the seeds Tarasevičienė et al.,(2019). Besides, it can be noticed that the mean value of total phenolic was $76.5 \mathrm{mg} / 100 \mathrm{~g}$ in normal barely while the highest value was $86.1 \mathrm{mg} / 100 \mathrm{~g}$ after germinated. Total flavonoids and total phenolic are increased significantly after germination. These results are in agreement with the results of Sharma \&Gujral ,2010; Dabina-Bicka et al., (2011) and El-Ashaal ,2013, who stated that phenolic content increased after germination because of hydrolysis by enzymes lead to get way phenolic component combined with lignin and arabinoxylase. It can be noticed that the value of total phenols and total flavonoids increased by $11.1,87.6 \%$ after germination. 
Table (2): Antioxidant activity, phenols and flavonoids content of normal and germinated barely

\begin{tabular}{||l|c|c|c|c|c||}
\hline \multicolumn{1}{|c|}{ Parameters } & $\begin{array}{c}\text { Normal } \\
\text { barely }\end{array}$ & $\begin{array}{c}\text { Germinated } \\
\text { barely }\end{array}$ & $\begin{array}{c}\text { \% } \\
\text { change }\end{array}$ & T & P \\
\hline DPPH scavenging activity $(\%)$ & $56.60 \pm 0.44$ & $82.12 \pm 0.47$ & 45.1 & $39.332^{*}$ & $<0.001^{*}$ \\
\hline Total phenols (mg/100g) & $76.5 \pm 0.05$ & $86.1 \pm 0.48$ & 11.1 & $19.935^{*}$ & $<0.001^{*}$ \\
\hline Total flavonoids (mg/100g) & $54.38 \pm 0.40$ & $102.0 \pm 0.48$ & 87.6 & $76.025^{*}$ & $<0.001^{*}$ \\
\hline
\end{tabular}

Data was expressed using Mean $\pm \mathrm{SE}$.

t: Student t-test

*: Statistically significant at $\mathrm{p} \leq 0.05$

\section{Some mineral content of normal and germinated barely}

A comparison between some mineral content of normal and germinated barely flour is shown in Table (3).

It can be observed that the content of some mineral such as $\mathrm{Ca}, \mathrm{Mg}, \mathrm{K}, \mathrm{Cr}$ and $\mathrm{Mn}$ of normal barely were 2.69,29.25, 208.05, 0.75 and $0.64 \mathrm{mg} / 100 \mathrm{~g}$, respectively which increased after germinated to reach $4.72,30.78,268.15,0.91$ and $0.78 \mathrm{mg} / 100 \mathrm{~g}$, respectively. It can be noticed that $\mathrm{Ca}, \mathrm{Mg}, \mathrm{K}, \mathrm{Cr}, \mathrm{Mn}$ increased by $75.5,5.0,28.8,21.3,21.9 \mathrm{mg} / 100 \mathrm{~g}$ after germination while $\mathrm{Fe}$ decreased by $17.4 \%$ after germination.

Barely grains are important sources of minerals which are important for biological process and Metabolic Functions (Demirbas, 2005). There were signicant differences of $\mathrm{Ca}, \mathrm{K} \& \mathrm{Fe}$ after germination,while there were no significant differences of $\mathrm{Mg}, \mathrm{Cr} \& \mathrm{Mn}$ after germination. These results are in agreement with the result of Al-Rdaddi ,2008. Magnesium was slightly increased after germination and that is important for heart activity and keep blood pressure, These results are in agreement with those findings of Hübner et al.,(2010) ; Plaza et al.,(2003) who reported that $\mathrm{Mg}$ content increased by germination for 3 days in barely.

The importance of Potassium $(\mathrm{K})$ is keeping alkaline acid balance in the body and keep liquid volume in the cells and transfere nerve stimuli from cell to the other, responsible for heart activity and keep blood pressure (Nawar, 2004). Raw barely grain contents of potassium increased by germination. These results are in agreement with Plaza et al., (2003) who reported that $\mathrm{K}$ content increased by germination, in contrast these results are not agreement with Hübner et al., (2010) who found that $\mathrm{K}$ were decreased by germination. Also 
calcium is very important for bones, teeth, coagulation of blood and decreasing colon cancer, Also calcium increased in germinated barely compared to raw barely grains. Fe ratio decreased in germinated, because of iron combine with phenolic substances in the water of soaking .Iron is important in hemoglobin creation and enzyme activation for creation of nerve stimuli (Nawar, 2004). These results are not agreement with Platel et al., (2010) who found that iron content was increased in malted barley. Mn is slightly increased after germinated. $\mathrm{Cr}$ and $\mathrm{Mn}$ are important in insulin creation and diabetic patients. These results are not agreement with Platel et al., (2010) who found that iron content was increased in germinated barely. The beneficial effect on iron and calcium availability after germination, Iron is another essential element for almost all living organisms, hulled barley malt had a double amount of iron that found in naked barley malt Abbaspour et al.,( 2014).

Table (3): Some mineral content of normal and germinated barely

\begin{tabular}{||l|c|c|c|c|c||}
\hline \multicolumn{1}{|c|}{ Minerals } & Normal barely & $\begin{array}{c}\text { Germinated } \\
\text { barely }\end{array}$ & $\begin{array}{c}\text { \% } \\
\text { change }\end{array}$ & $\mathbf{T}$ & $\mathbf{P}$ \\
\hline $\mathbf{C a}(\mathbf{m g} / \mathbf{1 0 0 g})$ & $2.69 \pm 0.14$ & $4.72 \pm 0.47$ & 75.5 & $4.156^{*}$ & $0.014^{*}$ \\
\hline $\mathbf{M g}(\mathbf{m g} / \mathbf{1 0 0 g})$ & $29.25 \pm 0.38$ & $30.78 \pm 0.49$ & 5.0 & 2.489 & 0.068 \\
\hline $\mathbf{K}(\mathbf{m g} / \mathbf{1 0 0 g})$ & $208.05 \pm 0.26$ & $268.15 \pm 0.26$ & 28.8 & $163.320^{*}$ & $<0.001^{*}$ \\
\hline $\mathbf{F e}(\mathbf{m g} / \mathbf{1 0 0 g})$ & $5.93 \pm 0.12$ & $4.90 \pm 0.06$ & -17.4 & $7.879^{*}$ & $0.001^{*}$ \\
\hline $\mathbf{C r}(\mathbf{m g} / \mathbf{1 0 0 g})$ & $0.75 \pm 0.30$ & $0.91 \pm 0.37$ & 21.3 & 0.336 & 0.754 \\
\hline $\mathbf{M n}(\mathbf{m g} / \mathbf{1 0 0 g})$ & $0.64 \pm 0.13$ & $0.78 \pm 0.47$ & 21.9 & 0.643 & 0.555 \\
\hline \hline
\end{tabular}

Data was expressed using Mean $\pm \mathrm{SE}$.

t: Student t-test

*: Statistically significant at $\mathrm{p} \leq 0.05$

\section{Determination of some vitamins contents of normal and germinated barely.}

A comparison between some vitamin content of normal and germinated barely $(\mathrm{mg} / 100 \mathrm{~g})$ is shown in Table (4) .Vitamins are organic chemical substances available in rarely amounts in food. Vitamins are very important in biological operations and prevent cancer. Vitamins devided into two groups save the body from cancer, artries and heart diseases. The lack of these vitamins 
cause functional disorder and infection with diseases. Vitamins are soluble in fats not in water and the vitamins which solubles in water are like vitamin B complex and vitamin C. Vitamin(E) decrease enzymes which create cholesterol in blood, vitamin $\mathrm{E}$ is available in grains not peeled grain (keeping outer husk) ,also grains are rich in vitamin B complex (El-Ashaal, 2013)

It can be observed in Table (4) that raw barley grains are rich in folic acid content and tocopherols and are free of pyridoxine. The germination process led to a slight increase in the content of both folic acid at a rate and in relation to vitamin $\mathrm{E}$ and pyrodoxine. The process of germination has a significant effect in the incidence of a significant increase in folic acid was $2.91 \%$ after germination while normal was $0.40 \%$. These results are in agreement with El-Ashaal ,2013 who mentioned that there was a significant increase of folic acid and pyridoxine B6 during the germination period for. Vitamin B helps in the production of red cells in the blood, that protect the body from synthesis and fatigue moreover strengthens the immune system and blood pressure.

The percentage value of vitamin E decreased from $\mathbf{5 . 6 6} \%$ for normal barely to $\mathbf{4 . 8 9} \%$ after germinated .These results are in agreement with DabinaBicka et al., (2011). Tocolates (vitamin $\mathrm{E}$ isomer) have an important physiological role in the body that includes antioxidant activity. Germination can change the vitamin $\mathrm{E}$ isomer content of edible seeds but the potential mechanisms involved are unclear. The effects of germination on vitamin $\mathrm{E}$ isomers also depend on the species Gan et al.,( 2017).

There was a highly significant difference between normal and germinated barely in folic acid and vitamin $\mathrm{B}_{6}$ content. It can be noticed that Folic acid increased by $627.5 \%$ after germination.

Table(4):Some vitamins content of normal and germinated barely (mg/100g).

\begin{tabular}{||l|c|c|c|c|c||}
\hline \multicolumn{1}{|c|}{ Parameters } & $\begin{array}{c}\text { Normal } \\
\text { barely }\end{array}$ & $\begin{array}{c}\text { Germinated } \\
\text { barely }\end{array}$ & $\begin{array}{c}\text { \% } \\
\text { change }\end{array}$ & T & P \\
\hline Folicacid(mg/100g) & $0.40 \pm 0.09$ & $2.91 \pm 0.03$ & 627.5 & $26.564^{*}$ & $<0.001^{*}$ \\
\hline B $_{\mathbf{6}}(\mathbf{m g} / \mathbf{1 0 0 g})$ & $0.0 \pm 0.0$ & $6.25 \pm 0.38$ & - & $16.523^{*}$ & $0.004^{*}$ \\
\hline Vitamin E (mg/100g) & $5.66 \pm 0.41$ & $4.89 \pm 0.24$ & -13.6 & 1.623 & 0.180 \\
\hline
\end{tabular}

Data was expressed using Mean $\pm \mathrm{SE}$.

t: Student t-test

$*$ : Statistically significant at $\mathbf{p} \leq \mathbf{0 . 0 5}$ 


\section{Determination of some anti-nutritional factors of normal and germinated barely:}

Anti-nutrition factors contents including Phytic acid, Tannins and Trypsin inhibitor was presented in table (5) .Grains which are used for human and animal consumption are known to contain a significant amount of tannin contents like barley (Hordeum vulgare) and a number of other legume seeds Kumar et al.,(2007). Furthermore, condensed tannin concentration in plant tissue has been shown to vary with species, plant part, plant maturity, drought, $\mathrm{CO}_{2}$ concentration and soil fertility Carter et al.,(1995). It can be observed that in table (5) the value of tannins decreased from $63.46 \mathrm{mg} / 100 \mathrm{~g}$ to 28.20 after germination. On the other hand, the value of phytic acid content decreased from 864.75 to 459.90 after germination. The value of Trypsin (low activity of trypsin inhibitor enzyme) was not detected.

Anti-nutritional factor discourage mineral elements absorption that obstruct the important cations like ( $\mathrm{Fe}, \mathrm{Mg}, \mathrm{Ca}, \mathrm{P}, \mathrm{Zn}$ ) .Decreasing vital values of these elements cause anemia and osteoporosis. Phytic acid also interferes with proteins during digestion. Phytic acid is a thermally stable, but its levels can be decreased with soaking in water and germination. Calcium and Potassium are the main elements in the ash of barely in the form of phytin and the enzyme of phytase break and hydrolise phytic acid to phosphoric acid and Inositol. The importance of phytic is that has the mostly amount of phosphorus Bouajila et al.,(2020).

Phytic acid hydrolysed during germination because of phytase enzyme Dai et al.,(2010). The content of phytic acid is $0.56 \%$ of the raw barely grains Tian et al.,( 2010) . Also these results are in agreement with Sonone ,2014 who found that phytic acid in raw barely grain is $8.7 \mathrm{mg} / 100 \mathrm{gm}$ and decreased to $2.3 \mathrm{mg} / 100 \mathrm{gm}$ during germination and soaking in water because of phytase enzyme. It can be noticed that tannin and Phytic acid decreased by 55.6 and $46.8 \%$ after germination.

Table (5):Anti-nutritional factors of normal and germinated barely

\begin{tabular}{||l|c|c|c|c|c||}
\hline \multicolumn{1}{|c|}{ Parameters } & Normal barely & $\begin{array}{c}\text { Germinated } \\
\text { barely }\end{array}$ & $\begin{array}{c}\% \\
\text { change }\end{array}$ & T & P \\
\hline Tannin (mg/100g) & $\mathbf{6 3 . 4 6} \pm \mathbf{0 . 1 5 m g / 1 0 0 g m}$ & $\mathbf{2 8 . 2 0} \pm \mathbf{0 . 4 0}$ & $\mathbf{- 5 5 . 6}$ & $\mathbf{8 2 . 7 5 0}$ & $<0.00{ }^{*}$ \\
\hline Phytic acid (mg/100g) & $\mathbf{8 6 4 . 7 5} \pm \mathbf{0 . 2 5 m g / 1 0 0 g}$ & $\mathbf{4 5 9 . 9 0} \pm \mathbf{0 . 3 8}$ & $-\mathbf{- 4 6 . 8}$ & $\mathbf{8 8 6 . 1 0 5}$ & $<0.001{ }^{*}$ \\
\hline Trypsin & - & - & & & \\
\hline
\end{tabular}

Data was expressed using Mean $\pm \mathrm{SE}$.

t: Student t-test

*: Statistically significant at $\mathrm{p} \leq 0.05$ 


\section{Determination of amino acid profile of normal and germinated barely:}

Amino acid profile was determined in normal and germinated barely flour. The essential amino acid was determined because of their importance for the nutritional value. Amino acids analysis showed that the protein contained nutritionally useful quantities of most of the essential amino acids but was low in Sulphur containing amino acids (Lotfy \& Nawar, 2014). The protein quality is defined by its amino acid composition and its digestibility. The protein digestibility primarily determines the availability of its amino acids (Maliwal, 1983). Amounts of dietary essential amino acids (EAA), digestibility of protein, and bioavailability of amino acids are basic parameters in determining the quality of a protein source (Food and Agriculture Organization [FAO] \& World Health Organization [WHO], 2001).

It is assumed that the chemical analysis reveals the amino acid liberated and absorbed from the gastro intestinal tract. On the other hand, a real estimate of a protein nutritive value can be made by comparing the amino acid pattern derived from the chemical analysis with a reference protein (Lotfy \& Nawar, 2014).

It is well established that each body tissue or organ is composed of special pattern of amino acids different from another tissue or organ .To build or repair them, all the needed amino acids must be presented qualitatively and quantitatively at the site of synthesis in abile temprory pool for a short period not exceeding several hours. Presence of an amino acid in a less quantity than needed will limit .The absence of one amino acid prevent building this tissue. Also, the excess of amino acid than tolerated by the body or un balanced amino acids will excerpt adverse effects on the body.Those undesirable impacts include toxic effect depressed growth. (Nawar, 2004).

The essential amino acids including Threonine, Lysine, Valine, Methionine, Isoleucine, Leucine, Phenylalanine and Histidine and non-essential amino acid including Aspartic, Arginine, Serine, Proline, Glutamic, Cystine, Glycine, Alanine and Tyrosine are shown in table (6) as a concentration percentage. Alanine level was the highest followed by leucine and lysein Moreover germinated barely had high value of essential leucine and lysine, methionine and phenylalanine. In general the results showed higher content of most of essential amino acids of germinated barely compare with normal.

It could be seen from table (6) that there was a trend to increase the content of essential and non -essential amino acid in germinated barely, 
alanine, leucine, methionine and lysine increased to the level of 13.09, 10.40, 8.86 , and $6.60 \mathrm{~g} / 100 \mathrm{gm}$ protein respectively; whereas in normal the content of alanine, leucine, methionine, lysine was 13.6, 3.31, 8.85 and $4.06 \mathrm{~g} / 100 \mathrm{~g}$ protein respectively. Similar results were previously reported by Tian et al.,(2010) who found that germination might offer a method for converting nutritionally poor-quality plant protein to a high quality for human consumption. The contents of isoleucine of normal barely was $1.81 \mathrm{~g} / 100 \mathrm{~g}$ protein while increased in germinated to $3.95 \mathrm{~g} / 100 \mathrm{~g}$ protein, and lysine content of germinated was also increased. These results are agreement with the result of Tkachuk \& Irvine ,1969 ; Youssef et al.,(2013) who approved that lysine content increased since germinated for $24 \mathrm{~h}$. It can be noticed that the percent increase of isoleucine, leucine, phenylalanine, lysine, cysteine and threonine were increased to $118.2,214.2,59.3,62.6,33.3$ and $37.6 \mathrm{~g} / 100 \mathrm{~g}$ protein respectively.

Leucine is an important akey in protein synthesis and has recently been identified as playing a critical role in insulin and Glucose metabolism (McClements, 2010). Cystein is the rate-limiting amino acid for synthesis of the ubiquitous antioxidant glutathione (GSH). Amino acid metabolism is essential to normal pancreatic $\beta$-cells function. Acutely, key amino acid such as alanine and glutamine can regulate $\beta$-cell function and insulin secretion.

The increase in the amino acids by germination might be due to an increase in proteolytic activity during sprouting desirable for nutritional improvement of cereals because it leads to hydrolysis of prolamins and the liberated amino acids such as glutamic and proline are converted to limiting amino acids such as lysine (Chavan \& Kadam, 1989; Onyeka \& Obeleagu, 2013). It could be seen from table (6) that an increase in the most of the essential amino acids. On the other hand, the first limiting amino acid was cystein in germinated barley and threonine was the second limiting amino acid in germinated barley. on the other hand Eaker ,1970 and Machado et al., (2020) they reported that Leucine was the highest essential amino acid while, methionine and histidine was low. Moreover, in raw barleys, valine was the second limiting amino acid. Table (6) indicated that alanine was high in germinated compared with normal barely. Trepel ,2004 reported that Leucine was the highest essential amino acid in barley grains. It could be seen from table (6) that germinated barley was a rich source of leucine, than normal. The current results showed that amino acid profile was increased after germination such as leucin, methionine, lysine and alanine. 
Table (6): Determination of amino acid profile in normal and germinated barely.

\begin{tabular}{|c|c|c|c|c|c|c|}
\hline & Amino acid & $\begin{array}{c}\text { Normal } \\
\text { barely }(\mathrm{gm} / 100 \\
\text { g protein })\end{array}$ & $\begin{array}{c}\text { Germinated } \\
\text { barely(gm/100g } \\
\text { protein) }\end{array}$ & $\begin{array}{c}\% \\
\text { change }\end{array}$ & $\mathbf{T}$ & $\mathbf{P}$ \\
\hline \multirow{10}{*}{ 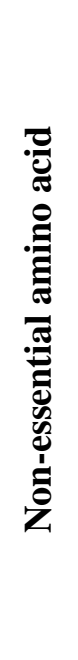 } & Aspartic acid & $3.10 \pm 0.26$ & $4.30 \pm 0.26$ & 38.7 & $3.258^{*}$ & $0.031^{*}$ \\
\hline & Glutamic acid & $7.10 \pm 0.10$ & $8.70 \pm 0.30$ & 22.5 & $5.134^{*}$ & $0.007^{*}$ \\
\hline & Serine & $6.20 \pm 0.09$ & $5.20 \pm 0.01$ & -16.1 & $10.675^{*}$ & $0.009^{*}$ \\
\hline & Glycine & $7.67 \pm 0.07$ & $6.50 \pm 0.28$ & -15.3 & $3.984^{*}$ & $0.016 *$ \\
\hline & Histidine & $9.09 \pm 0.14$ & $9.06 \pm 0.42$ & -0.3 & 0.056 & 0.958 \\
\hline & Arginine & $4.78 \pm 0.11$ & $5.65 \pm 0.48$ & 18.2 & 1.789 & 0.148 \\
\hline & Alanine & $13.06 \pm 0.26$ & $13.09 \pm 0.26$ & 0.2 & 0.082 & 0.939 \\
\hline & Proline & $6.68 \pm 0.21$ & $6.68 \pm 0.01$ & 0.0 & 0.015 & 0.990 \\
\hline & Tyrosine & $6.29 \pm 0.47$ & $6.38 \pm 0.14$ & 1.4 & 0.191 & 0.858 \\
\hline & Cysteine & $0.27 \pm 0.05$ & $0.36 \pm 0.03$ & 33.3 & 1.551 & 0.196 \\
\hline \multirow{7}{*}{ 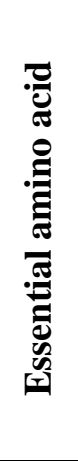 } & Threonine & $2.65 \pm 0.45$ & $3.65 \pm 0.45$ & 37.7 & 1.568 & 0.192 \\
\hline & Valine & $7.49 \pm 0.07$ & $6.48 \pm 0.10$ & -13.5 & 8.581* $^{*}$ & $\mathrm{O.001}^{*}$ \\
\hline & Methionine & $8.85 \pm 0.43$ & $8.86 \pm 0.19$ & 0.1 & 0.032 & 0.976 \\
\hline & Isoleucine & $1.81 \pm 0.05$ & $3.95 \pm 0.09$ & 118.2 & 21.292* & $<0.001$ \\
\hline & Leucine & $3.31 \pm 0.26$ & $10.40 \pm 0.26$ & 214.2 & $19.278^{*}$ & $<0.001 *$ \\
\hline & Phenylalanine & $3.56 \pm 0.49$ & $5.67 \pm 0.15$ & 59.3 & $4.107^{*}$ & $0.015^{*}$ \\
\hline & Lysine & $4.06 \pm 0.44$ & $6.60 \pm 0.04$ & 62.6 & $5.720^{*}$ & $0.005^{*}$ \\
\hline
\end{tabular}

Data was expressed using Mean \pm SE.

t: Student t-test

*: Statistically significant at $\mathrm{p} \leq 0.05$

\section{Rheological properties of normal and germinated barely :}

Rheological properties "water absorption \%, stability (min), Time gelatinization maximum (mm:ss), Gelatinization maximum (AU), Time of gelatinization begin (mm:ss), Begin of gelatinization temperature $\left({ }^{\circ} \mathrm{C}\right) "$ was performed. Results presented in table (7) illustrated that the gelatinization 
maximum for normal barely was $39.11 \mathrm{~mm}$ :ss compared with germinated barely was $23.24 \mathrm{~mm}$ :ss.Gelatinization maximum of normal barely was 781.0 AU, while germinated barely was10AU.The gelatinization temperature of normal and germinated barely flour were 88.70 and $64.80^{\circ} \mathrm{C}$ respectively. Time of gelatinization begin of normal and germinated barely flour were19.54 and 0.03 $\mathrm{mm}$ :ss respectively. Begin of gelatinization temperature were 58.80 and $30.0^{\circ} \mathrm{C}$ respectively.The percentage of water absorption of normal barely flour was $70.30 \%$ and $54.80 \%$ of germinated barely flour. Stability of normal and germinated barely flour were 6.08 and $6.17 \mathrm{~min}$, respectively. These results agreed with the result of Qiu et al., (2015) who approved that starch gelatinization process is influenced by the amylase-lipid complex formation, the amount of amylose leaching, the competition for free water between leached amylose and ungelatinised granules remained. A decrease in peak might be due to less swelling of the starch granules from germinated barely flour of whose compounds may interact with amylose. Also, it is possible that some compounds from germinated barely to compete with starch to absorb water during the starch gelatinization process that will create difficulties for starch to gelatinize.

The data in Table (7) showed that water absorption capacity (WAC) was decrease after germination treatment and that decrease might be due to degradation of starch in sprouting seeds. In this concept, Fincher and Stone (1986); Amri et al. (2016) they reported that, during the germination of barley grain, the nutritional reserves of the endosperm, mainly starch and proteins, had to be mobilized by a set of hydrolytic enzymes synthesized in the aleurone layer and in the scultellum of the germinating grain. Moreover, Greenwood \& Thamson ,1959; Perveen et al., (2010) and Vinje ,2015 found that the percentage of starch in the germinated barley was less than that in the original barley. Kinsella \& Melachouris ,1976 ; Petukhov et al., (2004) reported that, the function of proteins could hold water by hydrogen bonding or by physical entrapment. The increase might be due to ß-glucans which form viscous gels on hydration. Likewise, Munck ,1981; Tiwari \& Cummins ,2009 and Marcotuli et al.,(2020) found non starch polysaccharide $\beta$-glucan may influence (WAC). Moreover, Diwakar et al., (1996) ; Burkus \& Temelli ,2005 mentioned that during cooking, gelatinization of the carbohydrates and swelling of the crude fiber might occur which could also lead to increase water absorption.

On the contrary, Abbas et al., (2010) found a decrease in (WAC) with increasing temperature and they explained that by decomposition or degradation of starch. Ding et al., (2006) stated that the WAC decreased with increasing temperature if starch melting prevails over the gelatinization phenomenon. 
After these results using guar gum is a nessecary for improve stability and rheological properties of germinated barely flour to prepare some germinated barely products such as germinated barely, biscuits and talbina.

Table (7):Comparison between normal and germinated barely flour of rheological properties

\begin{tabular}{||l|c|c|c|c|c||}
\hline \multicolumn{1}{|c|}{ Parameters } & $\begin{array}{c}\text { Normal } \\
\text { barely }\end{array}$ & $\begin{array}{c}\text { Germinated } \\
\text { barely }\end{array}$ & $\%$ change & T & P \\
\hline $\begin{array}{l}\text { Time gelatinization } \\
\text { maximum(mm:ss) }\end{array}$ & $39.11 \pm 0.35$ & $23.24 \pm 0.10$ & -40.6 & $43.417^{*}$ & $<0.001^{*}$ \\
\hline $\begin{array}{l}\text { Gelatinization } \\
\text { maximum(AU) }\end{array}$ & $781.0 \pm 0.11$ & $10.0 \pm 0.43$ & -98.7 & $1748.117^{*}$ & $<0.001^{*}$ \\
\hline $\begin{array}{l}\text { Gelatinization } \\
\text { temperature }\left({ }^{\circ} \mathbf{C}\right)\end{array}$ & $88.70 \pm 0.26$ & $64.80 \pm 0.26$ & -26.9 & $64.947^{*}$ & $<0.001^{*}$ \\
\hline $\begin{array}{l}\text { Time of gelatinization } \\
\text { begin(mm;ss) }\end{array}$ & $19.54 \pm 0.08$ & $0.03 \pm 0.01$ & -99.8 & $61.320^{*}$ & $<0.001^{*}$ \\
\hline $\begin{array}{l}\text { Begin of gelatinization } \\
\text { temperature }\left({ }^{\circ} \mathbf{C}\right)\end{array}$ & $58.80 \pm 0.03$ & $30.0 \pm 0.10$ & -49.0 & $276.890^{*}$ & $<0.001^{*}$ \\
\hline \begin{tabular}{l} 
Water absorption $(\%)$ \\
\hline Stability (min)
\end{tabular} & $70.30 \pm 0.12$ & $54.80 \pm 0.18$ & -22.0 & $72.683^{*}$ & $<0.001^{*}$ \\
\hline \hline
\end{tabular}

Data was expressed using Mean $\pm \mathrm{SE}$.

t: Student t-test

*: Statistically significant at $\mathrm{p} \leq 0.05$

During germination many changes happened like roots formation and dissolving of the main components of the grain like starch because of the degradable enzymes like amylase enzyme which is responsible for hydrolyze starch and another changes during germination, so it is important to evaluate amylaze activity. Falling number is a measurements to measure alfa amylaze enzyme activity.

A comparison between falling number of normal and germinated barely is shown in Table (8). It can be observed that the effect of the germination process on the falling number of the barley flour, the mold of the device fell after 347 $\mathrm{sec}$ and the time decreased in the germinated barley to be $62.0 \mathrm{sec}$. These results are in agreement with the result of Ismail, 2007 who found that time of 
falling number decreased from $210 \mathrm{sec}$ for normal barely to $67 \mathrm{sec}$ for germinated barely. Warle et al., (2015) found that falling number was $240 \mathrm{sec}$ for raw barely and decreased to $80 \mathrm{sec}$ for germinated barely. The results in table (8) showed that barley flour was free from gluten. These results agreed with those reported by Izydorczyk \&Dexter ,2008 ; Hussein et al., (2013) while, Tanner et al., (2016) reported that barley grain (Hordeum vulgareL) was extremely low of gluten level.

Table (8):Falling number and wet gluten of normal and germinated barely.

\begin{tabular}{|l|c|c|c|c|c||}
\hline Parameters & Normal & Germinated & $\%$ change & T & P \\
\hline Falling No. & $347.0 \pm 0.14$ & $62.0 \pm 0.03$ & -82.1 & $1932.875^{*}$ & $<0.001^{*}$ \\
\hline Wet gluten & $0.0 \pm 0.0$ & $0.0 \pm 0.0$ & - & - & - \\
\hline
\end{tabular}

Data was expressed using Mean $\pm \mathrm{SE}$.

$\mathrm{t}$ : Student t-test

*: Statistically significant at $\mathrm{p} \leq 0.05$

\section{Conclusions}

The germination process played a significant role in improving chemical composition, nutritional value and rheological properties. Germination of raw barley increased its content of many vital compounds including phenols, flavonoids, mineral elements, fibers especially $\beta$-glucan. The content of folic acid, vitamin $\mathrm{E}$ and $\mathrm{B}$ complex also increased. Antioxidant activity significantly increased in barley upon germination. On the other hand, germination decreased the anti-nutritional factors and increased alpha amylase enzyme of raw barely. It is recommended to promote and encourage consumption of germinated barely and incorporate it in different food products to improve human health. 


\section{References}

Abbas, K., Khalil, S., \& Meor Hussin, A. S. (2010). Modified Starches and Their Usages in Selected Food Products: A Review Study. Journal of Agricultural Science, 2(2), 90-100.

Abbaspour, N., Hurrell, R., \& Kelishadi, R. (2014). Review on iron and its importance for human health. Journal of research in medical sciences, 19(2), 164-174.

Abdallah, M., \& Abo El-Naga, M. (2013). Use of seed sprouts flour to improve cake quality. Journal of Biological Chemistry and Environmental Sciences, 8(1), 279-298.

Abou-Bakr, T. M., Youssef, M. M., \& Moharram, H. A. (2014). Analysis, health benefits and applications of prebiotics: A review. Alexandria Journal of Food Science and Technology, 11(2), 25-37.

Afify, A. E.-M., Abbas, M. S., Abd El-Lattefi, B. M., \& Ali, A. M. (2016). Chemical, rheological and physical properties of germinated wheat and naked barley. International Journal of ChemTech Research, 9(9), 521531.

Agati, G., Azzarello, E., Pollastri, S., \& Tattini, M. (2012). Flavonoids as antioxidants in plants: location and functional significance. Plant science : an international journal of experimental plant biology, 196, 67-76.

Al-Rdaddi, A. M. (2008). Preparation and evaluation some functional foods using germinated barely grains and fractions (Master Thesis). UmmAlqura University, Kingdom of Saudi Arabi.

Amarowicz, R., Pegg, R., Rahimi-Moghaddam, P., Barl, B., \& Weil, J. (2004). Free-radical scavenging capacity and antioxidant activity of selected plant species from the Canadian prairies. Food chemistry, 84(4), 551562.

American Association of Cereal Chemists [AACC]. (2000). Approved methods of American Association of Cereal Chemists (10 ${ }^{\text {th }}$ ed.). Saint Paul: AACC, Inc.

Amri, B., Khamassi, K., Ali, M. B., Teixeira da Silva, J. A., \& Bettaieb Ben Kaab, L. (2016). Effects of gibberellic acid on the process of organic reserve mobilization in barley grains germinated in the presence of cadmium and molybdenum. South African Journal of Botany, 106, 3540. 
Antanas, S., Alexa, E., Negrea, M., Guran, E., \& Lazureanu, A. (2013). Studies regarding rheological properties of triticale, wheat and rye flours. Journal of Horticulture, Forestry and Biotechnology, 17(1), 345-349.

Association of Official Chemists [AOAC]. (2000). Official methods of analysis of AOAC International (17 ${ }^{\text {th }}$ ed.). washington, D.C: AOAC.

Bamforth, C. (1982). Barley $\beta$-glucan: their role in malting and brewing. Brewers Dig., 57(6), 22-27.

Batifoulier, F., Verny, M. A., Besson, C., Demigné, C., \& Rémésy, C. (2005). Determination of thiamine and its phosphate esters in rat tissues analyzed as thiochromes on a RP-amide C16 column. Journal of chromatography. B, Analytical technologies in the biomedical and life sciences, 816(1-2), 67-72.

Bonet, A., Blaszczak, W., \& Rosell, C. (2006). Formation of Homopolymers and Heteropolymers Between Wheat Flour and Several Protein Sources by Transglutaminase-Catalyzed Cross-Linking. Cereal Chemistry, 83, 655.

Bouajila, A., Ammar, H., Chahine, M., Khouja, M., Hamdi, Z., Khechini, J. . . . \& López, S. (2020). Changes in phytase activity, phosphorus and phytate contents during grain germination of barley (Hordeum vulgare L.) cultivars. Agroforestry Systems, 94, 1-9.

Brand-Williams, W., Cuvelier, M.-E., \& Berset, C. (1995). Use of a free radical method to evaluate antioxidant activity. LWT-Food science and Technology, 28(1), 25-30.

Brennan, C. S., \& Cleary, L. J. (2005). The potential use of cereal $(1 \rightarrow 3,1 \rightarrow$ $4)-\beta$-D-glucans as functional food ingredients. Journal of cereal science, 42(1), 1-13.

Burkus, Z., \& Temelli, F. (2005). Rheological properties of barley ß-glucan. Carbohydrate Polymers, 59, 459-465.

Carter, E., Morris, P., \& Theodorou, M. K. (1995). Environmental effects on chemistry and nutritive value of Lotus corniculatus (birdsfoot trefoil). In G. E. Pollot (Ed.), Grassland into the $21^{\text {st }}$ century: BGS Symposium $N^{\circ}$. 29 (p.p. 166-168). Harrogate: British Grassland Society.

Chandra, G. S., Proud, M. O., \& Baxter, E. D. (1999). The structure of barely Endosperm an important derminant of malt modification. Journal of the Science of Food and Agriculture, 79, 37-46.

Cohen, S. A., Mewyes, M., \& Travin, T. L. (1989). The pico-tag method. In C. Cooper, N. Packer \& K. Williams (Eds.), A manual of advanced techniques for amino acid analysis (p.p. 101-120). USA: Millipore. 
Cook, N. C., \& Samman, S. (1996). Flavonoids-chemistry, metabolism, cardioprotective effects, and dietary sources. The Journal of nutritional biochemistry, 7(2), 66-76.

Cozzolino, D., \& Degner, S. (2016). An overview on the role of lipids and fatty acids in barley grain and their products during beer brewing. Food Research International, 81, 114-121.

Chavan, J. K., \& Kadam, S. S. (1989). Nutritional improvement of cereals by fermentation. Critical reviews in food science and nutrition, 28(5), 349400.

Dabina-Bicka, I., Karklina, D., \& Kruma, Z. (2011). Polyphenols and vitamin E as potential antioxidants in barley and malt. Innovations for Food Science and Production. Faculty of Food Technology, Jetgawa, 121126.

Dai, F., Qiu, L., Xu, Y., Cai, S., Qiu, B., \& Zhang, G. (2010). Differences in Phytase Activity and Phytic Acid Content between Cultivated and Tibetan Annual Wild Barleys. Journal of Agricultural and Food Chemistry, 58(22), 11821-11824.

Daliu, P., Santini, A., \& Novellino, E. (2019). From pharmaceuticals tonutraceuticals: bridging disease prevention and management. Expert review of clinical pharmacology, 12(1), 1-7.

Davies, K. M., Albert, N. W., \& Schwinn, K. E. (2012). From landing lights to mimicry: the molecular regulation of flower colouration and mechanisms for pigmentation patterning. Functional plant biology : $F P B, 39(8), 619-638$.

Davies, N. T., \& Reid, H. (1979). An evaluation of the phytate, zinc, copper, iron and manganese contents of, and zn availability from, soya-based textured-vegetable-protein meat-substitutes or meat-extenders. The British journal of nutrition, 41(3), 579-589.

Delaux, P.-M., Nanda, A. K., Mathé, C., Sejalon-Delmas, N., \& Dunand, C. (2012). Molecular and biochemical aspects of plant terrestrialization. Perspectives in plant ecology, evolution and systematics, 14(1), 49-59.

Demirbas, A. (2005). $\beta$-Glucan and mineral nutrient contents of cereals grown in Turkey. Food Chemistry, 90(4), 773-777.

Ding, Q.-B., Ainsworth, P., Plunkett, A., Tucker, G., \& Marson, H. (2006). The effect of extrusion conditions on the functional and physical properties of wheat-based expanded snacks. Journal of food engineering, 73(2), 142-148. 
Diwakar, P., Kushwah, A., \& Kushwah, H. (1996). Effect of processing on the functional properties of some local varieties of Horsegram (Dolichos biflorus L.) in Madhya Pradesh. Journal of food science and technology, $33(2), 150-152$.

Donkor, O. N., Stojanovska, L., Ginn, P., Ashton, J., \& Vasiljevic, T. (2012). Germinated grains--sources of bioactive compounds. Food Chem, 135(3), 950-959.

Đorđević, T. M., Šiler-Marinković, S. S., \& Dimitrijević-Branković, S. I. (2010). Effect of fermentation on antioxidant properties of some cereals and pseudo cereals. Food chemistry, 119(3), 957-963.

Eaker, D. (1970). Determination of free and protein-bound amino acids. In A. E. Bender, B. LÖFqvist, R. Kihlberg \& L. Munck (Eds.), Evaluation of Novel Protein Products (p.p. 171-194). Oxford: Pergamon.

El-Ashaal, E. M. S. (2013). Studies on some functional foods (Master Thesis). Faculty of Agriculture, Mansoura University.

Fardet, A. (2010). New hypotheses for the health-protective mechanisms of whole-grain cereals: what is beyond fibre? Nutrition research reviews, 23(1), 65-134.

Fincher, G. B., \& Stone, B. A. (1986). Cell walls and their components in cereal grain technology. In Y. Pomeranz (Ed.), Advances in cereal science and technology (p.p. 207-295). Minnesota, USA: American Association of Cereal Chemists.

Folch, J., Lees, M., \& Sloane Stanley, G. H. (1957). A simple method for the isolation and purification of total lipides from animal tissues. The Journal of biological chemistry, 226(1), 497-509.

Food and Agriculture Organization [FAO], \& World Health Organization [WHO]. (2001). Report of the FAO/WHO Working Group on Analytical Issues Related to Food Composition and Protein Quality. Rome, Italy: FAO.

Francois, F. (1996). The visual foods encyclopedia. New York: Macmillan.Greenwood, B. T., \& Thamson, T. J. (1959). A composition of the starches from barley and malted barley. Journal of the Institute of Brewing, 65, 346-353.

Guillon, F., \& Champ, M. (2000). Structural and physical properties of dietary fibres, and consequences of processing on human physiology. Food research international, 33(3-4), 233-245. 
Gan, R.-Y., Lui, W.-Y., Wu, K., Chan, C.-L., Dai, S.-H., Sui, Z.-Q., \& Corke, H. (2017). Bioactive compounds and bioactivities of germinated edible seeds and sprouts: An updated review. Trends in Food Science \& Technology, 59, 1-14.

Greenwood, B. T., \& Thamson, T. J. (1959). A composition of the starches from barley and malted barley. Journal of the Institute of Brewing, 65, 346-353.

Hamerstrand, G., Black, L., \& Glover, J. (1981). Trypsin inhibitors in soy products: modification of the standard analytical procedure. Cereal Chemistry, 58(1), 42-45.

Han, X., Shen, T., \& Lou, H. (2007). Dietry polyphenol and their biological significance. International Journal of Molecular Science, 8, 950-988.

Harborne, J. B., \& Williams, C. A. (2000). Advances in flavonoid research since 1992. Phytochemistry, 55(6), 481-504

Heinrikson, R. L., \& Meredith, S. C. (1984). Amino acid analysis by reversephase high-performance liquid chromatography: precolumn derivatization with phenylisothiocyanate. Analytical biochemistry, 136(1), 65-74.

Hübner, F., O’Neil, T., Cashman, K. D., \& Arendt, E. K. (2010). The influence of germination conditions on beta-glucan, dietary fibre and phytate during the germination of oats and barley. European Food Research and Technology, 231(1), 27-35.

Hung, P. V., Maeda, T., Yamamoto, S., \& Morita, N. (2012). Effects of germination on nutritional composition of waxy wheat. J Sci Food Agric, 92(3), 667-672.

Hussein, A. M., Kamil, M. M., Hegazy, N. A., \& El-Nor, S. A. (2013). Effect of wheat flour supplemented with barely and/or corn flour on balady bread quality. Polish Journal of Food and Nutrition Sciences, 63(1), 11-18.

Ismail, S. A. (2007). Production of non- traditional food products from some barely varieties (Master Thesis). Institute of Environmental Studies and Research, Ain Shams University, Cairo.

Izydorczyk, M. S., \& Dexter, J. E. (2008). Barley $\beta$-glucan and arabinoxylans: Molecular structure, physicochemical properties, and uses in food products-a Review. Food Research International, 41(9), 850-868.

Jadhav, S. J., Lutz, S. E., Ghorpade, V. M., \& Salunkhe, D. K. (1998). Barley: chemistry and value-added processing. Critical reviews in food science and nutrition, 38(2), 123-171. 
Jribi, S., Chabbouh, M., Sassi, K., Sfayhi, D., Marzougui, S., Amara, H., \& Debbabi, H. (2018). Sprouting, a bioprocess supporting food industry? Journal of New Sciences, 57, 3725-3737.

Kaukovirta-Norja, A., Wilhelmson, A., \& Poutanen, K. (2004). Germination: a means to improve the functionality of oat. Agric Food Sci, 13, 100-112.

Kinsella, J. E., \& Melachouris, N. (1976). Functional properties of proteins in foods: a survey. Critical Reviews in Food Science \& Nutrition, 7(3), 219-280.

Kirkpatrick, L. A., \& Feeney, B. C. (2013). A simple guide to IBM SPSS statistics for version 20.0. Wadsworth: Cengage Learning.

Koehler, P., Hartmann, G., Wieser, H., \& Rychlik, M. (2007). Changes of folates, dietary fiber, and proteins in wheat as affected by germination. Journal of Agricultural and Food Chemistry, 55(12), 4678-4683.

Kotz, S., Balakrishnan, N., Read C. B, \& Vidakovic, B. (2006). Encyclopedia of statistical sciences $\left(2^{\text {nd }}\right.$ ed.). Hoboken: Wiley-Interscience.

Kryston, T. B., Georgiev, A. B., Pissis, P., \& Georgakilas, A. G. (2011). Role of oxidative stress and DNA damage in human carcinogenesis. Mutation research, 711(1-2), 193-201.

Kumar, V., Elangovan, A., Mandal, A., Tyagi, P., Bhanja, S., \& Dash, B. (2007). Effects of feeding raw or reconstituted high tannin red sorghum on nutrient utilisation and certain welfare parameters of broiler chickens. British poultry science, 48(2), 198-204.

Lotfy, T. R., \& Nawar, I. A. (2014). [Codification of food and meal management]. Kafr-El dawar: Boston El -Maref

Machado, M., Machado, S., Pimentel, F. B., Freitas, V., Alves, R. C., \& Oliveira, M. B. P. P. (2020). Amino Acid Profile and Protein Quality Assessment of Macroalgae Produced in an Integrated Multi-Trophic Aquaculture System. Foods, 9(10), 1382.

Makkar, H. P., Becker, K., Abel, H., \& Pawelzik, E. (1997). Nutrient contents, rumen protein degradability and antinutritional factors in some colourand white-flowering cultivars of Vicia faba beans. Journal of the Science of Food and Agriculture, 75(4), 511-520.

Maliwal, B. P. (1983). In vitro methods to assess the nutritive value of leaf protein concentrate. Journal of Agricultural and Food Chemistry, 31(2), 315-319.

Marcotuli, I., Colasuonno, P., Hsieh, Y. S. Y., Fincher, G. B., \& Gadaleta, A. (2020). Non-Starch Polysaccharides in Durum Wheat: A Review. International journal of molecular sciences, 21(8), 2933. 
Martirosyan, D., \& Jaishree, S. (2018). A new definition of functional food by FFC: creating functional food products using new definition. In D. Martirosyan (Ed.), Introduction to functional food science $\left(3^{\text {rd }}\right.$ ed p.p. 10-24). Dallas: Food Science Publisher.

McCleary, B. V., \& Codd, R. (1991). Measurement of $(1 \rightarrow 3),(1 \rightarrow 4)-\beta$-Dglucan in barley and oats: A streamlined enzymic procedure. Journal of the Science of Food and Agriculture, 55(2), 303-312.

McClements, D. J. (2010). Design of nano-laminated coatings to control bioavailability of lipophilic food components. Journal of food science, 75(1), R30-42.

McMurrough, I., \& Baert, T. (1994). Identification of proanthocyanidins in beer and their direct measurement with a dual electrode electrochemical detector. Journal of the Institute of Brewing, 100(6), 409-416.

Montanuci, F. D., Jorge, L. M. d. M., \& Jorge, R. M. M. (2013). Kinetic, thermodynamic properties, and optimization of barley hydration. Food Science and Technology, 33(4), 690-698.

Munck, L. (1981). Barley for food, feed and industry. In Y. Pomeranz \& L. Munck (Eds.), Cereals: a renewable resource, theory and practice (p.p. 427-459). Minnesota: American Association for Clinical Chemistry.

Naczk, M., \& Shahidi, F. (2004). Extraction and analysis of phenolics in food. Journal of chromatography. A, 1054(1-2), 95-111.

Nawar, I. A. (2004). Food and nutrition. Alexandria: Dar El-Maref Al-Gameea.

Nonogaki, H., Bassel, G. W., \& Bewley, J. D. (2010). Germination-still a mystery. Plant Science, 179(6), 574-581.

Onyeka, E. U., \& Obeleagu, O. S. (2013). Production and evaluation of specialty bread from sprouted mixed-grains. African Journal of Food Science, 7(4), 63-70.

Pejcz, E., Czaja, A., Wojciechowicz-Budzisz, A., Gil, Z., \& Spychaj, R. (2017). The potential of naked barley sourdough to improve the quality and dietary fibre content of barley enriched wheat bread. Journal of Cereal Science, 77, 97-101.

Perveen, A., Naqvi, I., Shah, R., \& Hasnain, A. (2010). Comparative Germination of Barley Seeds ( Hordeum Vulgare ) Soaked in Alkaline Media and Effects on Starch and Soluble Proteins. Journal of Applied Sciences and Environmental Management, 12, 5-9.

Petukhov, M., Rychkov, G., Firsov, L., \& Serrano, L. (2004). H-bonding in protein hydration revisited. Protein science, 13(8), 2120-2129. 
Platel, K., Eipeson, S. W., \& Srinivasan, K. (2010). Bioaccessible mineral content of malted finger millet (Eleusine coracana), wheat (Triticum aestivum), and barley (Hordeum vulgare). Journal of Agricultural and Food Chemistry, 58(13), 8100-8103.

Plaza, L., de Ancos, B., \& Cano, P. M. (2003). Nutritional and health-related compounds in sprouts and seeds of soybean (Glycine max), wheat (Triticum aestivum. L) and alfalfa (Medicago sativa) treated by a new drying method. European Food Research and Technology, 216(2), 138144.

Pollastri, S., \& Tattini, M. (2011). Flavonols: old compounds for old roles. Annals of botany, 108(7), 1225-1233.

Price, M. L., \& Butler, L. G. (1977). Rapid visual estimation and spectrophotometric determination of tannin content of sorghum grain. Journal of Agricultural and Food Chemistry, 25(6), 1268-1273.

Qiu, S., Yadav, M. P., Chen, H., Liu, Y., Tatsumi, E., \& Yin, L. (2015). Effects of corn fiber gum (CFG) on the pasting and thermal behaviors of maize starch. Carbohydr Polym, 115, 246-252.

Sangronis, E., Rodriguez, M., Cava, R., \& Torres, A. (2006). Protein quality of germinated Phaseolus vulgaris. European Food Research and Technology, 222(1), 144-148.

Santini, A., \& Novellino, E. (2018). Nutraceuticals - shedding light on the grey area between pharmaceuticals and food. 11(6), 545-547.

Santini, A., Tenore, G. C., \& Novellino, E. (2017). Nutraceuticals: A paradigm of proactive medicine. European journal of pharmaceutical sciences, 96, 53-61.

Shahidi, F. (2012). Nutraceuticals, functional foods and dietary supplements in health and disease. Journal of food and drug analysis, 20(1), 226-230.

Sharma, P., \& Gujral, H. S. (2010). Antioxidant and polyphenol oxidase activity of germinated barley and its milling fractions. Food Chemistry, 120(3), 673-678.

Sharma, S., Gambhir, S., \& Munshi, S. K. (2007). Changes in lipid and carbohydrate composition of germinating. Asian Journal of Plant Sciences, 6(3), 502-507.

Siddhuraju, P., \& Becker, K. (2003). Antioxidant properties of various solvent extracts of total phenolic constituents from three different agroclimatic origins of drumstick tree (Moringa oleifera Lam.) leaves. Journal of Agricultural and Food Chemistry, 51(8), 2144-2155. 
Soares, R., De Francisco, A., Rayas-Duarte, P., \& Soldi, V. (2007). Brazilian hull-less and malting barley genotypes: I. Chemical composition and partial characterization. Journal of food quality, 30(3), 357-371.

Sonone, A. P. (2014). Production of soy-fortified weaning food. International Journal of Advanced Research, 2, 41-50.

Tanner, G. J., Blundell, M. J., Colgrave, M. L., \& Howitt, C. A. (2016). Creation of the first ultra-low gluten barley (Hordeum vulgare L.) for coeliac and gluten-intolerant populations. Plant biotechnology journal, 14(4), 1139-1150.

Tarasevičienè, Ž., Viršilè, A., Danilčenko, H., Duchovskis, P., Paulauskienė, A., \& Gajewski, M. (2019). Effects of germination time on the antioxidant properties of edible seeds. CyTA-Journal of Food, 17(1), 447-454.

Tian, B., Xie, B., Shi, J., Wu, J., Cai, Y., Xu, T. . . . \& Deng, Q. (2010). Physicochemical changes of oat seeds during germination. Food Chemistry, 119(3), 1195-1200.

Tiwari, U., \& Cummins, E. (2009). Factors Influencing $\beta$-Glucan Levels and Molecular Weight in Cereal-Based Products. Cereal Chemistry 86, 290301.

Tkachuk, R., \& Irvine, G. (1969). Amino acid compositions of cereals and oilseed meals. Cereal Chemistry, 46, 206-218.

Trepel, F. (2004). [Dietary fibre: more than a matter of dietetics. I. Compounds, properties, physiological effects]. Wiener klinische Wochenschrift, 116(14), 465-476.

Vinje, M. (2015). Comparison of Factors Involved in Starch Degradation in Barley Germination Under Laboratory and Malting Conditions. Journal of the American Society of Brewing Chemists, 73, 195-205.

Wall, M. M. (2006). Ascorbic acid, vitamin A, and mineral composition of banana (Musa sp.) and papaya (Carica papaya) cultivars grown in Hawaii. Journal of Food Composition and analysis, 19(5), 434-445.

Warle, B. M., Riar, C. S., Gaikward, S. S., \& Mane, V. A. (2015). Effect of germination on nutritional quality of barely. International Journal of Food and Nutritional Sciences, 4(1), 59-63.

Winkel-Shirley, B. (2001). Flavonoid biosynthesis. A colorful model for genetics, biochemistry, cell biology, and biotechnology. Plant physiology, 126(2), 485-493.

Winkel-Shirley, B. (2002). Biosynthesis of flavonoids and effects of stress. Current opinion in plant biology, 5(3), 218-223. 
Yao, L. H., Jiang, Y. M., Shi, J., Tomás-Barberán, F. A., Datta, N., Singanusong, R., \& Chen, S. S. (2004). Flavonoids in food and their health benefits. Plant foods for human nutrition (Dordrecht, Netherlands), 59(3), 113-122.

Youssef, M. K. E., El-Fishawy, F., Ramadan, E., \& Abd El-Rahman, A. (2013). Nutritional Assessment of Barley, Talbina and Their Germinated Products. Frontiers in Science, 3(2), 56-65.

Youssef, M. K. E., El-Fishawy, F., Ramadan, E.-S. A. E.-N., \& El-Rahman, A. M. (2012). Assessment of total lipid fractions and fatty acids composition in raw, germinated barleys and talbina products. Food and Public Health, 2(1), 16-23.

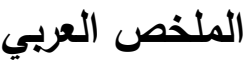

\section{تأثير الإنبات في الشعير علي تركيبه الكيميائي وقيمته الغذائية وخواصه الريولوجيه}

يعتبر الثعير غذاء وظيفي فهو مصدر جيد لمضادات الأكسدة والألياف الغذائية مثل بيتا جلوكان. تهدف الدراسة الحالية إلى تقييم صفات للشعبر العادي والثُنبت. و قد نم ذلك عن طريق تقدير تأثنير الإنبات على محتوي مضادات الأكسدة ، ومحتوى العوامل المضادة للتغذية ، ومحتوى الأحماض الأمينية ، وبعض الفيتامينات والمعادن ، والخصائص الريولوجية (قرة رفع العجين) للشعير العادي الإدي

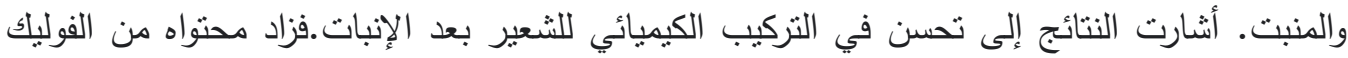
اسيد، فيتامين هـ وفيتامين ب المركب وزاد محتوي الثعبر من المعادن منل الكروم الماغنسيوم والكالسيوم وانخفض محتواه من مضادات التغذية منل التانيين والفيتيك اسيد وزاد محتوي الثعبر من الاحماض الامينية مثل الليسين والليوسين و أظهرت النتائج زيادة في محتويات الفلافونويدات والفينولات إلى جانب نشاط مضادات الأكسدة في الشعير المنبت ، وتوصي الدراسة الي تعزيز وتتجيع استهلاك منتجات

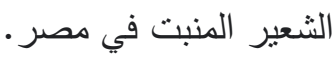

